\title{
pÿ For Women are Not Worthy of Life : Protology and Misogyny in Gospel of Thomas Saying 114
}

\section{Miroshnikov, Ivan}

Brill

2017

pÿMiroshnikov , I 2017, For Women are Not Worthy of Life : Protology and Misogyny in Gospel of Thomas Saying 114 . in U Tervahauta , I Miroshnikov, O Lehtipuu \& I Dunderberg (eds), Women and Knowledge in Early Christianity . Supplements to Vigiliae Christianae, pÿno. 144 , Brill , Leiden , pp. 175186 . https://doi.org/10.1163/9789004344938_010

http://hdl.handle.net/10138/311356

https://doi.org/10.1163/9789004344938_010

publishedVersion

Downloaded from Helda, University of Helsinki institutional repository.

This is an electronic reprint of the original article.

This reprint may differ from the original in pagination and typographic detail.

Please cite the original version. 
PART 3

Women in Ancient Intellectual Discourse 
Ivan Miroshnikov - 9789004344938

Downloaded from Brill.com02/10/2020 03:34:48PM via University of Helsinki 


\title{
"For Women are Not Worthy of Life": Protology and Misogyny in Gospel of Thomas Saying 114*
}

\author{
Ivan Miroshnikov
}

In his article on the role of women disciples in the Gospel of Thomas, Professor Antti Marjanen refers to saying 114 as "one of the most studied and debated logia in the entire gospel." Marjanen's article has undoubtedly proven to be a prominent voice in the discussion of this saying. This volume, celebrating Professor Marjanen's contribution to the scholarship of early Christianity, offers an appropriate opportunity to revisit and build on his interpretation of the debated logion. Below is the Coptic text of the saying along with its English translation:

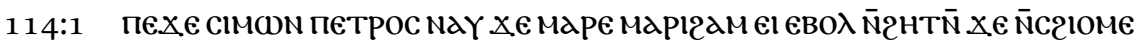

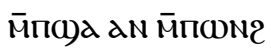

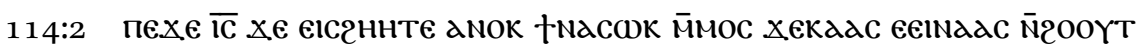

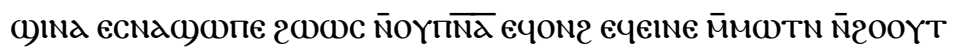

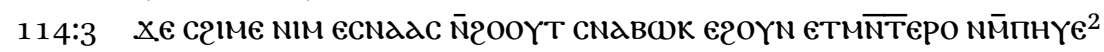

114:1 Simon Peter said to them, "Let Mary leave us, for women are not worthy of life."

114:2 Jesus said, "I myself shall lead her in order to make her male, so that she too may become a living spirit resembling you, men.

114:3 For every woman who will make herself male will enter the kingdom of heaven." 3

* I wish to thank Dmitry Bratkin, Ismo Dunderberg, Kenneth W. Lai, and Alexey Somov for commenting on previous versions of this text.

1 Antti Marjanen, "Women Disciples in the Gospel of Thomas," in Thomas at the Crossroads: Essays on the Gospel of Thomas, ed. Risto Uro, SNTw (Edinburgh: T\&T Clark, 1998), 95, with bibliography. For studies on this saying published after 1998, see Simon Gathercole, The Gospel of Thomas: Introduction and Commentary, TENTS 11 (Leiden: Brill, 2014), 6o7.

2 The Coptic text is reproduced from Bentley Layton, ed., Nag Hammadi Codex II, 2-7 together with XIII, 2 * , Brit. Lib. Or. 4926 (1), and P. Oxy. 1, 654, 655, N HS 20-21 (Leiden: Brill, 1989), 1:92.

3 I have modified Thomas O. Lambdin's translation from Layton, Nag Hammadi Codex II, 2-7, 1:93. 
In what follows, I offer a reflection on the Coptic text of the saying, its possible mythological background, and its place in the composition of the Gospel of Thomas.

\section{The Text of Gospel of Thomas 114:2}

The Berliner Arbeitskreis für koptisch-gnostische Schriften translates oүnīd

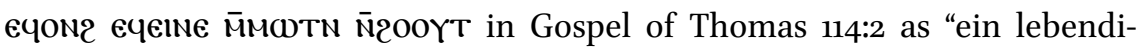
ger, euch gleichender, männlicher Geist."4 As Uwe-Karsten Plisch explains, "Here Ñ20oYT 'male' is understood as syntactically equal to the two previous attributive circumstantial clauses EqON2 and eqeine MMMOTN. All three parts are attributes of ormind 'spirit." ${ }^{5}$ Despite Peter Nagel's objections to this translation, ${ }^{6}$ it seems to be perfectly grammatical, as illustrated by the following example from the Authoritative Discourse, where an attributive noun is preceded by an attributive circumstantial clause: ${ }^{7}$

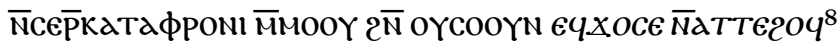

(God wished) that they despise them with exalted, incomprehensible knowledge. ${ }^{9}$

4 Kurt Aland, ed., Synopsis quattuor evangeliorum: Locis parallelis evangeliorum apocryphorum et patrum adhibitis, 15th ed., 4th printing (Stuttgart: Deutsche Bibelgesellschaft, 2005), 545 .

5 Uwe-Karsten Plisch, The Gospel of Thomas: Original Text with Commentary, trans. Gesine Schenke Robinson (Stuttgart: Deutsche Bibelgesellschaft, 2008), 247 n. 4. See also HansGebhard Bethge, “'Werdet vorübergehende': Zur Neubearbeitung des Thomasevangeliums für die Synopsis Quattuor Evangeliorum," in Bericht der Hermann Kunst-Stiftung zur Förderung der neutestamentlichen Textforschung für die Jahre 1995 bis 1998 (Münster: Hermann Kunst-Stiftung zur Förderung der neutestamentlichen Textforschung, 1998), 5o; Uwe-Karsten Plisch, "Probleme und Lösungen: Bemerkungen zu einer Neuübersetzung des Thomasevangeliums (N HC II, 2)," in Schrifttum, Sprache und Gedankenwelt, vol. 2 of Ägypten und Nubien in spätantiker und christlicher Zeit: Akten des 6. Internationalen Koptologenkongresses, Münster, 20.-26. Juli 1996, ed. Stephen Emmel et al., skco 6:2 (Wiesbaden: Reichert, 1999), $5^{28}$.

6 See Peter Nagel, "Die Neuübersetzung des Thomasevangeliums in der Synopsis quattuor evangeliorum und in Nag Hammadi Deutsch Bd. 1,"ZNW 95 (2004): 255-256.

7 The linguistic terminology used in this chapter follows Bentley Layton, A Coptic Grammar, with Chrestomathy and Glossary: Sahidic Dialect, 3rd ed., PLO NS 20 (Wiesbaden: Harrassowitz, 2011).

8 Auth. Disc., NHC VI 26.16-18; see Douglas M. Parrott, ed., Nag Hammadi Codices V, 2-5 and VI with Papyrus Berolinensis 8502, 1 and 4, N HS 11 (Leiden: Brill, 1979), 268.

9 I have modified Marvin Meyer's translation from Marvin Meyer, ed., The Nag Hammadi Scriptures (New York: HarperOne, 2007), 385. 
Two more passages attest to the phenomenon, though in these examples the circumstantial clause functions adverbially:

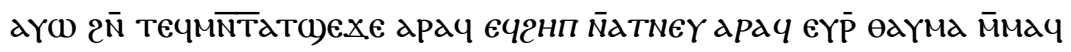
$2 \overline{\mathrm{N}}$ OYNOYC $^{10}$

And being hidden and invisible in his ineffability, he is admired in the mind (trans. Einar Thomassen). ${ }^{11}$

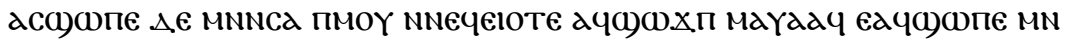

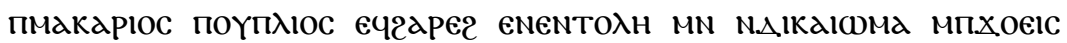

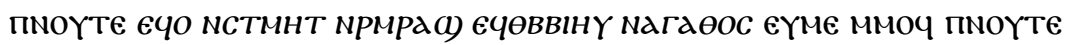
MN NPWME ${ }^{12}$

And it came to pass, after the death of his parents, he remained alone and stayed with the blessed Publius, keeping the commandments and the ordinances of the Lord God, being obedient, gentle, humble, and good, beloved by God and the people (translation mine).

However, the suggestion of the Berliner Arbeitskreis is still problematic. As Simon Gathercole notes, "there is a certain tautology in a translation along the lines of '... so that I might make her male, so that she also might be a living male spirit ....'13 It seems reasonable, therefore, to interpret $\overline{\mathrm{N}}$ 20OYT as a direct

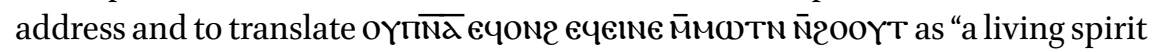
resembling you, men." This understanding of N̄20oYT receives support from the Sahidic New Testament, where $\overline{\mathrm{N}}$ ¿ooYT often corresponds to the vocative oi ävopes of the Greek text. ${ }^{14}$

10 Tri. Trac., NHC I 63.21-22; see Louis Painchaud and Einar Thomassen, eds., Le Traité tripartite (NH I, 5), BCNHT 19 (Québec: Les Presses de l'Université Laval, 1989), 8o and 82.

11 Marvin Meyer, ed., The Nag Hammadi Scriptures (New York: HarperOne, 2007), 67.

12 Martyrdom of Leontius of Tripoli 3.5; see Gérard Garitte, "Textes hagiographiques orientaux relatifs à saint Léonce de Tripoli. I. La passion copte sahidique," Mus 78 (1965): 321. This example is from Alla I. Elanskaya, A Coptic Grammar: Sahidic Dialect [in Russian] (St. Petersburg: Nestor-Historia, 2010), 318 (§1045).

13 Gathercole, Gospel of Thomas, $615^{-616 .}$

14 See Eph 5:25; Col 3:19; 1 Pet 3:7. In all these instances, the nominative usurps upon the domain of the vocative; see Friedrich Blass, Albert Debrunner, and Robert W. Funk, 


\section{The Text of Gospel of Thomas 114:3}

Another suggestion of the Berliner Arbeitskreis concerns the meaning of $x \in$ in Gospel of Thomas 114:3. According to Hans-Gebhard Bethge,

In 114:3 bedarf das einleitende $x \in$ einer genaueren Bestimmung. Bisher wurde es ganz überwiegend kausal verstanden, wodurch freilich ganz deutlich sachliche Spannungen zur Aussage Jesu in 114:2 unvermeidlich sind. U.E. ist nun das $x \in$ als eine einem ö $\tau \iota$ recitativum entsprechende Konjunktion aufzufassen, die antecedenslos in elliptischer Ausdrucksweise eine erneute direkte Rede einleiten soll. Vorauszusetzen ist dabei ein imaginäres $+\chi \propto \Delta \epsilon \bar{M} M O C($ NHTT $)=$ "Ich aber sage (euch)." ${ }^{15}$

According to Plisch, a similar case of a "mere" $\chi €$ introducing direct speech is attested in the Gospel of Judas (CT 45.14). ${ }^{16}$ However, while the proposal of the Berliner Arbeitskreis is quite ingenious, it is hardly appealing. As Nagel notes, there are various instances of $x \in$ used in a causal/explicative sense at the end of a Thomasine saying. ${ }^{17}$ What is perhaps even more important is that the saying follows a parallel structure: in Gospel of Thomas 114:1, Simon Peter first pronounces a statement about Mary and then offers justification for this statement by making a claim about women in general. In Gospel of Thomas 114:2, Jesus also makes a claim about Mary and then, in Gospel of Thomas 114:3, justifies this claim by means of a general statement about women. In both cases, the general claim is introduced with $x \in$. The parallelism of the saying is clear: Mary-women / Mary-women ( $\mathrm{A}-\mathrm{B} / \mathrm{A}-\mathrm{B})$. Indeed, parallelism is one of the most critically important structural devices in the Gospel of Thomas. ${ }^{18}$ To interpret $x \in$ in Gospel of Thomas 114:3 as a conjunction introducing direct speech would thus mean to disregard the poetics of both this particular saying and the saying collection as a whole.

A Greek Grammar of the New Testament and Other Early Christian Literature (Chicago: University of Chicago Press, 1961), 81-82 (§147).

15 Bethge, "Zur Neubearbeitung des Thomasevangeliums," 5 o. See also Plisch, "Probleme und Lösungen," 528; Aland, Synopsis quattuor evangeliorum, 546 n. 165 .

16 Plisch, Gospel of Thomas, 247 n. 9.

17 Nagel, "Neuübersetzung des Thomasevangeliums," 256-257.

18 See, e.g., Ivan Miroshnikov, "The Gospel of Thomas and Plato: A Study of the Impact of Platonism on the 'Fifth Gospel'" (PhD diss., University of Helsinki, 2016), 189-19o. 


\section{Marjanen on Saying 114}

Having discussed the text of saying 114, I turn now to its contents. While men are considered "living spirits," women neither are nor have any part in salvation. The only way, rather, for a woman to gain salvation is to become male. By virtue of becoming male, she will then become a "living spirit," which in turn will grant her salvation.

Marjanen has especially focused on the representation of women disciples in the Gospel of Thomas. With respect to Simon Peter's harsh words in Gospel of Thomas 114:1, Marjanen notes, "Nowhere else in early Christian literature does one find an equally negative view of women." ${ }^{19}$ Moreover, while elsewhere the words of the disciples merely reveal their ignorance (sayings 51, 52, 99, 104, etc.), in Gospel of Thomas 114:2-3 Jesus implicitly agrees with Simon Peter's statement. ${ }^{20}$ Although the notion of "making female male" has parallels in second-century Valentinian sources, ${ }^{21}$ in these texts, both men and women are innately "female" and must both become "male." In saying 114, on the other hand, only women are in need of change. ${ }^{22}$

These observations incline Marjanen toward Stephen J. Patterson's reading of the saying. ${ }^{23}$ As Marjanen points out, the Thomasine notion of "making female male" "could have been understood very concretely," and it is thus possible that saying 114 might be a witness to an early Christian practice of female cross-dressing. ${ }^{24}$ Marjanen also hypothesizes that saying 114 could have

19 Marjanen, "Women Disciples," 104.

$20 \quad$ Marjanen, "Women Disciples," 102.

21 Clement of Alexandria, Exc. 21.3 (cf. Exc. 79); Heracleon, fr. 5 (= Origen, Comm. Jo. 6.111).

22 Marjanen, "Women Disciples," 102-103.

23 Stephen J. Patterson, The Gospel of Thomas and Jesus: Thomas Christianity, Social Radicalism, and the Quest of the Historical Jesus, FF: Reference Series (Sonoma: Polebridge Press, 1993), 153-155. Patterson draws upon the work of Elizabeth Castelli; see Elizabeth Castelli, "Virginity and Its Meaning for Women's Sexuality in Early Christianity," JFSR 2 (1986): 7576; Castelli, "'I Will Make Mary Male': Pieties of the Body and Gender Transformation of Christian Women in Late Antiquity," in Body Guards: The Cultural Politics of Gender Ambiguity, ed. Julia Epstein and Kristina Straub (London: Routledge, 1991), 43-44.

24 Marjanen, "Women Disciples," 99-10o. Most of the early examples of Christian women cutting their hair and wearing male dress come from the apocryphal acts: Acts Paul 3:25; 4:15; Acts Thom. 114 (Greek version); Acts Phil. 4:6; 8:4; cf. Acts Andr. 19. The version of Acts Phil. 8 attested in the manuscript Atheniensis 346 (mentioned in Marjanen, "Women Disciples," 100) has since been published: see François Bovon, Bertrand Bouvier, and Frédéric Amsler, eds., Acta Philippi: Textus, ccsA 11 (Turnhout: Brepols, 1999), 237-275 (text and French translation); François Bovon and Christopher R. Matthews, The Acts 
been a later addition to the text of the Gospel of Thomas, "added to the collection in a situation in which the role of women in the religious life of the community had for some reason become a matter of debate." 25

Whatever the case, it is clear that the author of saying 114 is confident that women can attain salvation, even though the words he puts into Jesus's mouth are pronouncedly misogynistic. ${ }^{26}$ In what follows, I build on Marjanen's interpretation of saying 114 by discussing a possible mythological background to the saying's misogyny.

\section{Living Spirits}

In Gospel of Thomas 114:1, Simon Peter says that women do not deserve to live. What underlies this statement is the very ubiquity of misogyny in the ancient world. Indeed, examples are plentiful: Plato, for instance, famously wrote that all wicked men are reborn as women, ${ }^{27}$ while Aristotle insists that we "must look upon the female character as being a sort of natural deficiency

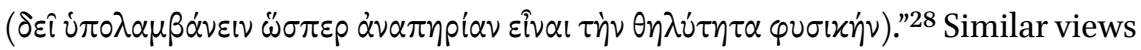
were maintained by various writers throughout the period of antiquity; for instance, Aristotle's thoughts are echoed in Philo: "It is said by the natural philosophers that the female is nothing else than an imperfect male ( $\lambda \dot{\varepsilon} \gamma \varepsilon \tau \alpha \mathrm{l}$

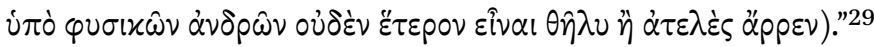

However, Jesus's response to Simon Peter in Gospel of Thomas 114:2 seems to imply that the reasons for the author's misogyny are more specific: women do not deserve to live, because they are not "living spirits." Where, then, does the notion that men are "living spirits" come from?

of Philip: A New Translation (Waco, Tx: Baylor University Press, 2012), 74-80 (English translation). Other early sources that seem to attest to this practice are Herm. Vis. 3.8.4 (16.4) and Lucian, Fug. 27. The latter example, noted in Patterson, Gospel of Thomas and Jesus, 154 , is especially revealing, since it seems to attest to female cross-dressers among non-Christians.

25 Marjanen, "Women Disciples," 103.

26 Marjanen, "Women Disciples," 100.

27 Tim. 42a-d; 9oe.

28 Gen.an. 775a15-16 (trans. A. Platt). Cf. 737a27-28: "For the female is, as it were, a mutilated

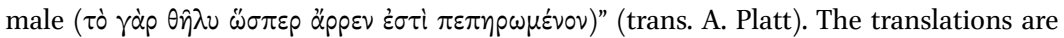
from Jonathan Barnes, ed., The Complete Works of Aristotle, Bollingen Series 71:2 (Princeton: Princeton University Press, 1995), 1:1199 and 1:1144.

29 QE 1.7; cf. QG 1.25. 
I am inclined to agree with scholars who understand this expression as an allusion to the second account of creation according to Genesis. ${ }^{30}$

Two details of this account are relevant for the present discussion. First, God

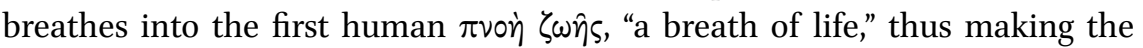
human $\psi v \times \grave{\eta} \zeta \hat{\omega} \sigma \alpha$, "a living soul" (Gen 2:7). ${ }^{31}$ Second, while according to the first account of creation, the created human ( $\delta \dot{\alpha} v \theta \rho \omega \pi \circ \varsigma)$ was both male and female (Gen 1:27), the second account claims that God first (Gen 2:7) created the human ( $\delta \dot{\alpha} \nu \theta \rho \omega \pi \circ \varsigma)$, called "Adam" ( $\delta$ 'A $\delta \dot{\alpha} \mu)$, and only later (Gen 2:22) fashioned a woman ( $\gamma v v \eta$ ) from the rib that he had taken from Adam. Although the second account of creation does not explicitly state that the first human was male, it is clear that it was interpreted this way by at least some of its ancient readers. ${ }^{32}$

I suggest that the Thomasine notion of a "living spirit" was inspired by the creation narrative of Genesis 2:7 and that Gospel of Thomas 114:2 says that only men are "living spirits" because the first human of Genesis 2:7 was male. An objection might be leveled against this point, since the word "spirit" ( $\pi v \varepsilon \hat{\mu} \mu)$ does not occur in Genesis 2:7. However, the biblical text does employ a cognate to $\pi \nu \varepsilon \hat{\mu \alpha}$, viz. $\pi \nu \eta^{\prime}$, and at least some ancient readers of Genesis 2:7 certainly thought that the text spoke about $\pi v \varepsilon v \hat{\mu} \alpha$. Our best evidence on this point comes from Philo, who writes that what God breathed into the human was nothing other than a "divine spirit," $\pi \nu \varepsilon \hat{\mu} \mu \alpha \theta \varepsilon \hat{0}{ }^{33}$ Philo also makes the case that, in Genesis 2:7, Moses calls the human soul $\pi v \varepsilon \hat{u} \mu \alpha^{34}$ Occasionally, when

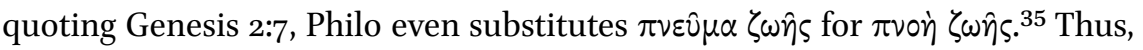
even though a modern reader would perhaps prefer the Thomasine Jesus to be faithful to the text of Genesis and speak of "a living soul" rather than of "a living spirit," it is likely that the author of the saying was simply not concerned with philological precision.

$30 \quad$ See Pheme Perkins, "The Gospel of Thomas," in A Feminist Commentary, vol. 2 of Searching the Scriptures, ed. Elisabeth Schüssler Fiorenza (London: SCм Press, 1995), 558-56o; April D. DeConick, Seek to See Him: Ascent and Vision Mysticism in the Gospel of Thomas, VCSup 33 (Leiden: Brill, 1996), 19-20; Hans Kvalbein, "The Kingdom of the Father in the Gospel of Thomas," in The New Testament and Early Christian Literature in Greco-Roman Context: Studies in Honor of David E. Aune, ed. John Fotopoulos, NovTSup 122 (Leiden: Brill, 20o6), 214.

Here and elsewhere, the text of Genesis is from the Septuagint. It seems very unlikely that saying 114 would presuppose the Hebrew version rather than the Greek one.

32 See, for instance, 1 Tim 2:13.

33 Opif. 135 .

34 Det. 84.

$35 \quad$ Leg. 3.161; Det. 8o. 
Thus, Simon Peter's claim that women do not deserve to live is likely based on a particular reading of the second account of creation. Adam, the first man, was the one whom God made a living being (Gen 2:7). To live, i.e. to attain salvation, means to return to the prelapsarian condition of the first living being; since the first living being was male, maleness is a prerequisite of salvation. Femaleness, on the other hand, has nothing to do with life.

\section{Mary on Trial?}

If indeed the symbolic world of saying 114 revolves around a specific reading of the Genesis narrative, it is plausible that the author of the saying was also reading the whole of Genesis either critically or selectively, i.e. endorsing some verses and disagreeing with/ignoring others. ${ }^{36}$ Indeed, while the scriptural passage that deals with the creation of woman (Gen 2:22) does not say anything about life, in Genesis 3:20, we read that Adam "called the name of his wife Life $\left(\zeta \omega \eta^{\prime}\right),{ }^{37}$ because she is the mother of all the living" (NETS). Why would women not deserve to live, then, if "Life" was the name of the first woman?

At the risk of going beyond the evidence provided by the text, I would like to make the following tentative suggestion. In the biblical text, Genesis 3:20 is immediately preceded by the story of the Fall. It seems likely that the author of saying 114 held Eve responsible for this catastrophic event and thus considered Genesis 3:20 to be in direct contradiction with the preceding narrative. The notion that the Fall resulted from the malicious actions of the first woman is attested in 1Timothy 2:14 ("and Adam was not deceived, but the woman was deceived and became a transgressor," NRSV) and other ancient sources. ${ }^{38}$ It is thus possible that, from the viewpoint of saying 114, women are unworthy of life due to the troubles the first woman inflicted upon the humankind. By no means would the author of the saying deem the first woman worthy of the name "Life."

36 I have borrowed the term "selective reading" from Hugo Lundhaug and Lance Jenott, The Monastic Origins of the Nag Hammadi Codices, sTAC 97 (Tübingen: Mohr Siebeck, 2015), 267 .

37 The Greek text attempts to preserve the word play of the original Hebrew text, wherein

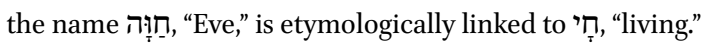

38 See, for instance, Life of Adam and Eve 9:2; 10:2; 11:1-2; 14:2; 32:2. My references follow the versification of the Greek version. For parallels in the Latin, Armenian, Georgian, and Slavonic versions, see Gary A. Anderson and Michael E. Stone, eds., A Synopsis of the Books of Adam and Eve, 2nd ed., EJL 17 (Atlanta: Scholars Press, 1999). 
Interestingly, the assumption that in saying 114 women are pronounced unworthy of life because all human misfortunes were caused by Eve's transgression may, in turn, shed some light on the very expression $\bar{M} \Pi)_{2}$ d in Gospel of Thomas 114:1. The only parallel to the Thomasine expression "not worthy of life" seems to be Acts 13:46, where Paul and Barnabas say to the Jews, "It was necessary that the word of God should be spoken first to you. Since you reject it and judge yourselves to be unworthy of eternal life (oủx à $\xi i o u \varsigma x p i-$

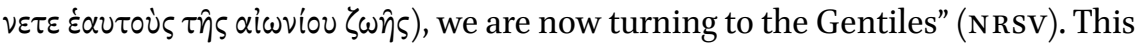
expression is clearly a reformulation of another expression, "to be worthy of

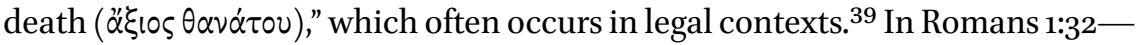
"They know God's decree, that those who practice such things deserve to die"

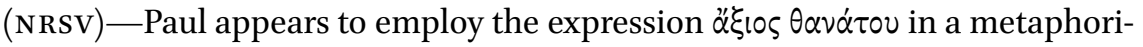
cal sense: as Joseph A. Fitzmyer notes, "death" here seems to refer not to physical death, but to exclusion from the kingdom of God (cf. Rom 6:23).$^{40}$ Similarly, both Acts 13:46 and Gospel of Thomas 114:1 repurpose what was initially a legal expression to refer to those who do not deserve salvation, i.e. Jews and women. However, in Acts 13:46, the author still bears in mind the legal nature of this expression: the Jews "judge" themselves unworthy of eternal life. In Gospel of Thomas 114:1, on the other hand, the connection between this expression and the realm of law is no longer evident.

Yet it is not improbable that the author of saying 114 used the expression "not worthy of life" intentionally, in order to indicate that the dialogue between Simon Peter and Jesus takes place during a trial of sorts, wherein Simon Peter indicts Mary, and Jesus pronounces her sentence. At this "trial," women were "found guilty" of the Fall and "sentenced" to (spiritual) death; hence, Simon Peter's request to expel Mary from the collegium of Jesus's disciples. Jesus, however, is offering "release on probation": should Mary—or any other womanfree herself from her own femaleness, she will enter the kingdom of heaven.

\section{Saying 114 and the Composition of the Gospel of Thomas}

As noted above, Marjanen suggested that saying 114 could have been a later addition to the text of the Gospel of Thomas. Building upon the work of Stevan

\footnotetext{
39 See, for instance, Xenophon, Mem. 1.1.1, where the prosecutors persuaded the Athenians that Socrates deserves to die.

40 Joseph A. Fitzmyer, Romans: A New Translation with Introduction and Commentary, AB 33 (New York: Doubleday, 1993), 289-29o.
} 
L. Davies, ${ }^{41}$ Marjanen offered several arguments in favor of the secondary character of the saying: the tension between the notion of "making female male" and the annulment of gender promoted in saying $22,{ }^{42}$ the fact that saying 113 seems to form a thematic unit with saying 3 and "could thus be a natural ending for the collection," and the multiple parallels to the motif of "making female male" in second- and third-century Christian writings. ${ }^{43}$

These arguments merit serious scholarly consideration, though, admittedly, with regard to the theory of saying 114 as a later addition and the compositional history of the Gospel of Thomas in general, there seems to be no methodologically sound procedure that would lead us to definitive conclusions. Whatever the case, it is worth noting that the person who decided to place saying 114 at the end of the collection was well-acquainted with the rest of the text. As I have already noted, the parallel structure of saying 114 is in tune with the poetics of the Gospel of Thomas. Moreover, although some of the features of the saying are admittedly unique, ${ }^{44}$ its language has remarkable parallels in other sayings. Most importantly, while the expression "not worthy of life" occurs only in saying 114, the language of "being worthy" (expressed with either Coptic $\bar{M} \Pi{ }^{2}$ d or Greco-Coptic dz.10c) appears also in sayings 55, 56, 80, 85, 111, and possibly also $62 .{ }^{45}$ Of those, saying 85 is of special interest, as it deals with the unworthiness of the protoplast: ${ }^{46}$

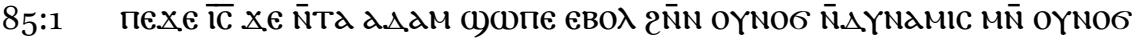

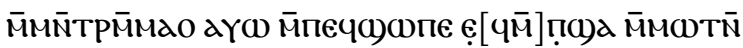

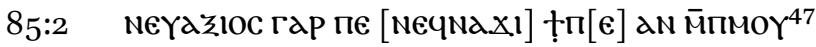

41 Stevan L. Davies, The Gospel of Thomas and Christian Wisdom (New York: The Seabury Press, 1983), 152-153.

42 On the idea of becoming asexual in saying 22 as a subcase of the Thomasine motif of becoming one, a motif largely shaped by Platonist thought, see Miroshnikov, "Thomas and Plato," 86-113.

43 Marjanen, "Women Disciples," 103; see also n. 24, above.

44 As Marjanen notes, for instance, no other Thomasine saying begins with a disciple addressing other disciples; see Marjanen, "Women Disciples," 103.

45 In saying 62 , the word $\overline{\mathrm{M}} \Pi() \mathrm{d}$ likely occurs in the lacuna, as there appears to be no other meaningful way to restore the Coptic text. Moreover, the restoration is supported by a possible allusion to saying 62 in Origen, Comm. Matt. 14.14; see Matteo Grosso, "A New Link between Origen and the Gospel of Thomas: Commentary on Matthew 14,14," vc 65 (2011): 249-256.

46 This saying presents us with a number of challenges, most importantly the interpretation of the "great power" and "great wealth," but it is not my intent to address them here.

Layton, Nag Hammadi Codex II, 2-7, 1:70. 
85:1 Jesus said, "Adam came into being from a great power and a great wealth, but he did not become worthy of you.

85:2 For had he been worthy, [he would] not [have experienced] death".48

The notion of experiencing (literally, "tasting") death in Gospel of Thomas 85:2 immediately reminds the reader of saying 1 , according to which, "whoever finds the interpretation of these sayings will not experience death" (trans. Thomas O. Lambdin). Thus, the true disciples of Jesus are worthier than Adam, because, unlike him, they will never die. For the purposes of the present discussion, it is worth noting that saying 85 contrasts Adam's divine origins with his human death, the latter of which proved that Adam was unworthy. It seems very likely that the saying presupposes the notion of Adam's transgression, which resulted in the advent of death (cf. Rom 5:12). ${ }^{49}$

Thus, saying 85 appears to stand in contrast to saying 114. According to saying 85 , Adam's transgression made him mortal and therefore unworthy; according to saying 114, on the other hand, Eve was the transgressor and therefore unworthy of life. This contrast provides us with yet another example of the tension between saying 114 and the rest of the collection, and thus can be compounded with Marjanen's evidence for the saying's secondary nature, yet it can hardly serve as the conclusive argument. On the other hand, the tension between sayings 85 and 114 may provide us with an opportunity to gain better insight into the reasoning behind the position of saying 114 at the end of the collection. Perhaps the purpose of saying 114 was in anticipation of certain misreadings of the Gospel of Thomas. The reader of the collection might come to the conclusion that both genders are equally abominable (saying 22), or even that our male protoplast was solely responsible for our expulsion from the paradise (saying 85). The author of saying 114 might have exposed the deficiency of femininity to avoid precisely such interpretations; hence, the unparalleled misogyny of the saying.

\section{Conclusion}

Professor Antti Marjanen's article "Women Disciples in the Gospel of Thomas" contains valuable insights into the meaning and background of saying 114. The purpose of this chapter was to revisit and build upon Marjanen's observations.

48 Layton, Nag Hammadi Codex II, 2-7, 1:71.

49 Plisch, Gospel of Thomas, 195. 
First, I have argued that $\overline{\mathrm{N}}$ 20OYT in saying 114:2 should be understood as a direct address. Thus, according to this saying, men, unlike women, are "living spirits." Second, I have suggested that this notion draws upon Genesis 2:7, where God makes Adam, our male protoplast, a "living soul." Thus, women are not worthy of life, because, in the beginning, life was given to men. Third, it is also possible that, from the perspective of the author of saying 114, the creation of woman had tragic consequences for the history of salvation. Thus, yet another reason for women not to deserve to live is the maliciousness of the first woman and the catastrophic consequences of her actions. Fortunately, according to Jesus, a woman can free herself from her own femaleness, attain the condition of the primordial man (i.e. transform into a "living spirit"), and, by doing so, attain salvation. Finally, I have argued that saying 114 could have been designed to prevent the reader from misinterpreting the rest of the collection, which, according to the author of the saying, would have failed to emphasize the worthlessness of womanhood. 